\title{
THE MULTIPLIER IMPACT OF EUROPEAN UNION FUNDING ON HIGHER EDUCATION AND RESEARCH IN THE PORTUGUESE REGIONS UNDER HORIZON 2020
}

\author{
N. Jesus Silva \\ Universidade Portucalense, Infante D. Henrique (PORTUGAL)
}

\begin{abstract}
The objective of the European Higher Education and Research H2020 Program is to increase the number of higher education graduates and to support new PhDs in order to strengthen research, technological development and innovation.
\end{abstract}

The partnership agreement between the European Union and the Member States for the implementation of the European Structural and Investment Funds (FEEI), for the period 2014-2020, the European Regional Development Fund (ERDF), the Cohesion Fund (CF), the Fund European Social Fund (ESF), the European Agricultural Fund for Rural Development (EAFRD), the European Maritime and Fisheries Fund (EMFF), is in its final phase.

It is therefore important to understand the impact on public and private investment that the partnership agreement is having in the different regions and consequently in the member countries.

Support for regional investment has allowed the construction or modernization of collective infrastructures, such as schools, promotion of cultural and natural heritage, bets on energy efficiency, promotion of information and communication technologies (ICT) in public services, research and development, as well as urban rehabilitation and mobility. In this area, inter-municipal and business investments are also included.

The present study analyzes the multiplier impact on regional investment of European funds made available to the Lisbon - Portugal region under the H2020 program until September 2018, in the areas of higher education and the strengthening of research.

The aim is to understand whether the objectives proposed by the European Union in relation to the financial support granted by the EU/investment provided in the various regions in 1,28 are being achieved, and on the other hand, respond to the main research question:

a) What is the value invested in the regional economy in the areas of higher education and research and development for each euro of support allocated by the European Union through the H2020 program in the different regions of Portugal.

The entity responsible for the management of Community support has been requested to provide information on the number of projects approved, amounts invested by type of investment and their support granted by the European Union up to 30/09/2018.

From the data received, the analysis was structured in relation to four main intervention areas: 1) Municipal investment; 2) Business investment; 3) Science and technology; 4) territorial approaches.

In each of the areas, the data was available in order to obtain the following information: total support granted by the $\mathrm{H} 2020$ program, eligible investment, total investment and number of projects supported and so we can respond to the main research question.

Keywords: Education, Europe, Investment, Municipalities, Research.

\section{INTRODUCTION}

On 12 June 1985 Portugal signed the Treaty of Accession to the European Economic Community (EEC). The Prime Minister Mário Soares led the entourage that formalized, in the Mosteiro dos Jerónimos, the entry into the European project.

Portugal was experiencing a serious financial crisis, accentuated by the recession of the world economy. After the revolution of 25 April 1974, and the loss of the colonial market, Portugal maintained a great external dependence. It is in this context that the country is approaching the European market, applying 
for membership of the EEC in 1977. It is only in the following decade that this request is made (1986), simultaneously with Spain, in what was the third enlargement of the European group.

The European Economic Community is part of the process of forming what is now the European Union, which had its origin in the intention to foster economic progress, freedom and a lasting peace between the neighboring states of Europe.

It began in 1950 in the European Coal and Steel Community (ECSC) with six founding countries: Germany, Belgium, Italy, France, Luxembourg and the Netherlands, which took the first steps towards the union of the countries of Europe.

Mateus (1992) said that the changes brought about the full accession of Portugal to the EEC in 1986, in the context of the elimination of tariff, technical and fiscal barriers, required by the completion of the European internal market by the end of 1993 , have been a fundamental framework for rigorously situating the different experiences, policies and actions to promote development, whether at the sectoral level or at the regional level, or at the national level.

Portugal's full membership of the European Communities has triggered a significant process of modernization of economic structures and behavior in parallel with the global liberalization of markets. In a context where public intervention has clearly been polarized by the promotion of important investments of an infrastructural nature, namely , railways and ports, telecommunications, energy, science and technology, education and vocational training, among others, which are facilitated by access to structural funds of Community origin and with some background in the country's regional development prospects.

This development represented the culmination of a long process of European integration and was part of a broader economic, social and political restructuring.

\subsection{The Community financing framework 2014-2020}

The Partnership Agreement that Portugal has proposed to the European Commission, called Portugal 2020 , adopts the programming principles of the Europe 2020 Strategy and enshrines the economic, social, environmental and territorial development policy that will stimulate growth and job creation in the coming years in Portugal.

The correction of the budgetary and external imbalances of the Portuguese economy, the main objective of the Economic and Financial Adjustment Plan adopted by Portugal since 2011, has negative social consequences and asymmetric impacts on the development of the various regions. Public policies, in particular those co-financed by Community funds, should therefore promote growth and employment, with a view to reducing poverty and correcting the external imbalance that still exists.

The programming and implementation of Portugal 2020 is organized in four thematic areas competitiveness and internationalization, social inclusion and employment, human capital, sustainability and efficiency in the use of resources - also considering the transversal domains related to public administration reform and the territorialisation of interventions. The identification of the main constraints and potentialities of these areas has made it possible to define the priorities for Community funding for the period 2014-2020.

The constraints in the area of competitiveness and internationalization are related to the fact that productive specialization is based on activities of low added value, low technological intensity and knowledge, weak skills and strategies of companies inherent to the fragility of the qualification of employers and employees and their low propensity for more sophisticated business strategies. The difficult conditions of business context, namely the financing conditions of the companies and the increased costs and transport times given the geographical position of Portugal in Europe and the distance from the main export destinations are other of the constraints felt.

The following public policy instruments are foreseen:

direct incentives for business investment, especially in $R$ \& $D$, qualification of SMEs focused on internationalization strategies;

indirect support to business investment to enable companies to pursue more advanced business strategies;

support for qualified and creative entrepreneurship and empowerment of the most dynamic business opportunities and in areas of innovation; 
support for the production and dissemination of scientific and technological knowledge, promoting the international linkages of national and regional $R \& D$ systems, as well as the transfer of knowledge and technology between companies, R \& D centers and higher education;

support for business training to train the company's human resources for innovation and internationalization processes; investments in transport infrastructures, focused on reducing transportation time and costs for companies, especially in the context of international connectivity;

and support for the administrative modernization and training of the Public Administration, aiming at reducing the public costs of context.

As regards the field of social inclusion and employment, there is a high level of unemployment due to the recent economic crisis, aggravated by the fact that long-term unemployment affects more than half of the unemployed and the number of young people who are not employed, nor to study or in training, have increased significantly.

It is also a constraint, the strong segmentation of the labor market, between a more qualified segment, tending to have higher employability and quality of employment, and a segment that is less qualified or with inadequate qualifications to the needs of the productive fabric, with unemployment risks access to precarious employment. In this area, and to these associated factors, a high level of poverty and social exclusion persist in Portugal.

In this area, and to these associated factors, a high level of poverty and social exclusion persist in Portugal. Thus, with a view to promoting employment and social inclusion, Community support is assumed for the following policy instruments:

Asset qualification, for the development of skills certified for the labor market;

Transition from situations of inactivity or unemployment to employment, as well as the net creation of employment and maintenance in the labor market;

Consolidation and re-qualification of the collective equipment and services network;

Specific interventions in favor of territories or target groups in which the situations or risks of poverty are cumulative with those of social exclusion; promotion of gender equality, non-discrimination and accessibility, complementary to those referred to above; combat failure and early school leavers.

These public policy instruments will be properly coordinated with the numerous instruments that by their nature will not benefit from Community funding.

In the so-called Human Capital domain, there is a lag in relation to the more developed countries of the average qualification level of the adult and young population (associated with the late schooling of the Portuguese population, the reduced participation of the adult population in education and certified training activities and early school leavers); the lack, despite the improvement, of a quality and efficient education and training system; and the mismatch between the skills produced and those sought by the labor market.

It is therefore important to envisage direct interventions to reduce drop-out rates and promote educational success; promote vocational training offers for young people; guarantee school social action (in primary, secondary and higher education); and provide higher-level training.

The main constraints that Portugal still faces in the area of Sustainability and Efficiency in the use of Natural Resources are synthesized in the high-energy intensity of the Portuguese economy, in the inefficient use and management of resources, in vulnerabilities in face of diverse natural and technological risks and in the weaknesses in the protection of values. The approach to responding to these constraints is structured in three vectors which will be the basis for the mobilization of the EU funds of the next cycle: the transition to a low carbon economy, mainly associated with the promotion of energy efficiency and the production and distribution of renewable energy; risk prevention and adaptation to climate change; the protection of the environment and promotion of resource efficiency, structured around the intervention areas: waste management; water management (urban water cycle and management of water resources); management, conservation and enhancement of biodiversity; recovery of environmental liabilities; qualification of the urban environment, especially as a result of regeneration and urban revitalization.

The Partnership Agreement was subject to an ex ante evaluation which consisted of an interactive process of reflection which led to the consideration of incorporating the recommendations made in the successive versions. One of the main conclusions is that the diagnosis underpinning the Partnership 
Agreement and its recommendations and the identification of the thematic areas to be considered are convergent and consistent with the objectives and targets of the Europe 2020 Strategy and the National Reform Program. The logic of intervention of the funds is organized around the thematic areas already mentioned and of two dimensions of a transversal nature, the thematic objectives selected from those provided for in Community regulations, the investment priorities mobilized for the intended purposes and the specific objectives and expected results for each of them.

To complete the description of the programming logic, the operational delimitation (intervention of each Fund and Operational Financing Program) and the territorial scale of intervention (national and regional articulation) are presented.

The Partnership Agreement applied the principle of partnership, based on work by the Government, Public Administration, various civil society entities and the general public. Of particular note is the involvement of the institutional, economic and social partners in the preparatory work for the 2014-2020 cycle, in particular the Assembly of the Republic, the Economic and Social Council, the Standing Social Dialogue Commission (involving trade union centrals and business organizations) and the National Association of Portuguese Municipalities. There were also initiatives for the dissemination and consultation of civil society. The principle of equality between men and women, non-discrimination and accessibility, and the principle of sustainable development were also guaranteed. The governance model of the Partnership Agreement and Operational Programs 2014-2020 and its institutional architecture aims at four objectives:

simplification of the governance model, focusing on the one hand the segregation of responsibilities and institutional support for the exercise of the functions of political orientation and technical, and valuing on the other hand the involvement of the partners;

results orientation, materialized through the valorization of the results in the decisions of financing and their evaluation and consequent consequences in the payments of final balance of the projects;

the establishment of common rules for financing, which not only ensure conditions of fairness and transparency, but also competition between beneficiaries;

and simplifying beneficiaries' access to funding and reducing their administrative costs. This programming exercise presents an assessment of compliance with national ex ante conditionalities. For those cases where, according to the evaluation referred to, conditionalities are not met, action plans were established in accordance with Article 19 of Regulation (EU) 1303/2013. The principle of additionality was also verified.

In order to ensure the performance analysis of all instruments, implementing the mechanism provided for in the Fund's regulatory framework, called the Performance Framework, initiatives have been developed to ensure consistency in the selection of indicators in programming.

Lastly, the territorial development strategies adopted which will contribute to the territorial strengthening of the Europe 2020 Strategy are explained, ensuring that the specificities and different degrees of development of the subregions are taken into account, ensuring the involvement of subregional entities and regional and local authorities in the planning and implementation of their programs and projects.

Portugal 2020 is the Partnership Agreement between Portugal and the European Commission, which brings together the five European Structural and Investment Funds - ERDF, Cohesion Fund, ESF, EAFRD and FEAMP - which programming that enshrines the policy of economic, social and territorial development to promote, in Portugal, between 2014 and 2020.

These programming principles are aligned with Intelligent, Sustainable and Inclusive Growth, pursuing the Europe 2020 Strategy.

Portugal will receive around 25 billion euros by 2020; to this end, defined the Thematic Objectives to stimulate growth and the creation of Employment, the necessary interventions to achieve them and the achievements and the expected results with these financing:

Stimulating the production of tradable goods and services;

Increase in exports;

Transfer of results from the scientific system to the productive fabric;

Compulsory schooling until the age of 18 ; reduction of levels of early school leaving;

Integration of people at risk of poverty and combating social exclusion; 
Promotion of sustainable development from the point of view of efficiency in the use of resources;

Strengthening territorial cohesion, particularly in cities and low-density areas; rationalization, modernization and training of Public Administration are the main policy objectives to be pursued in Portugal 2020.

The programming and implementation of Portugal 2020 is organized in four thematic areas: Competitiveness and Internationalization; - Social inclusion and employment; - Human capital; Sustainability and Efficiency in the Use of Resources. It also considers the cross-cutting areas related to public administration reform and the territorialisation of interventions.

In terms of eligibility for the European Investment Funds (ERDF, CF, ESF, FEADER and FEAMP), the 7 regions of Portugal are divided into:

Less developed regions (GDP per capita $<75 \%$ EU average): North, Center, Alentejo and Autonomous Region of the Azores (RAA)

Fund co-financing rate: $85 \%$

Transition regions (GDP per capita between $75 \%$ and $90 \%$ ): Algarve

Co-financing rate of the Funds: $80 \%$

More developed regions (GDP per capita> 90\%): Lisbon and the Autonomous Region of Madeira (ARM)

Co-financing rate of the Funds: $50 \%$ (Lisbon) and $85 \%$ (ARM)

Portugal will receive EUR 25 billion by 2020 for all funds, which will be allocated under each of the 16 Operational Programs, thematic and regional, as shown in the following chart:

Table 1 - Operational, thematic and regional programs:

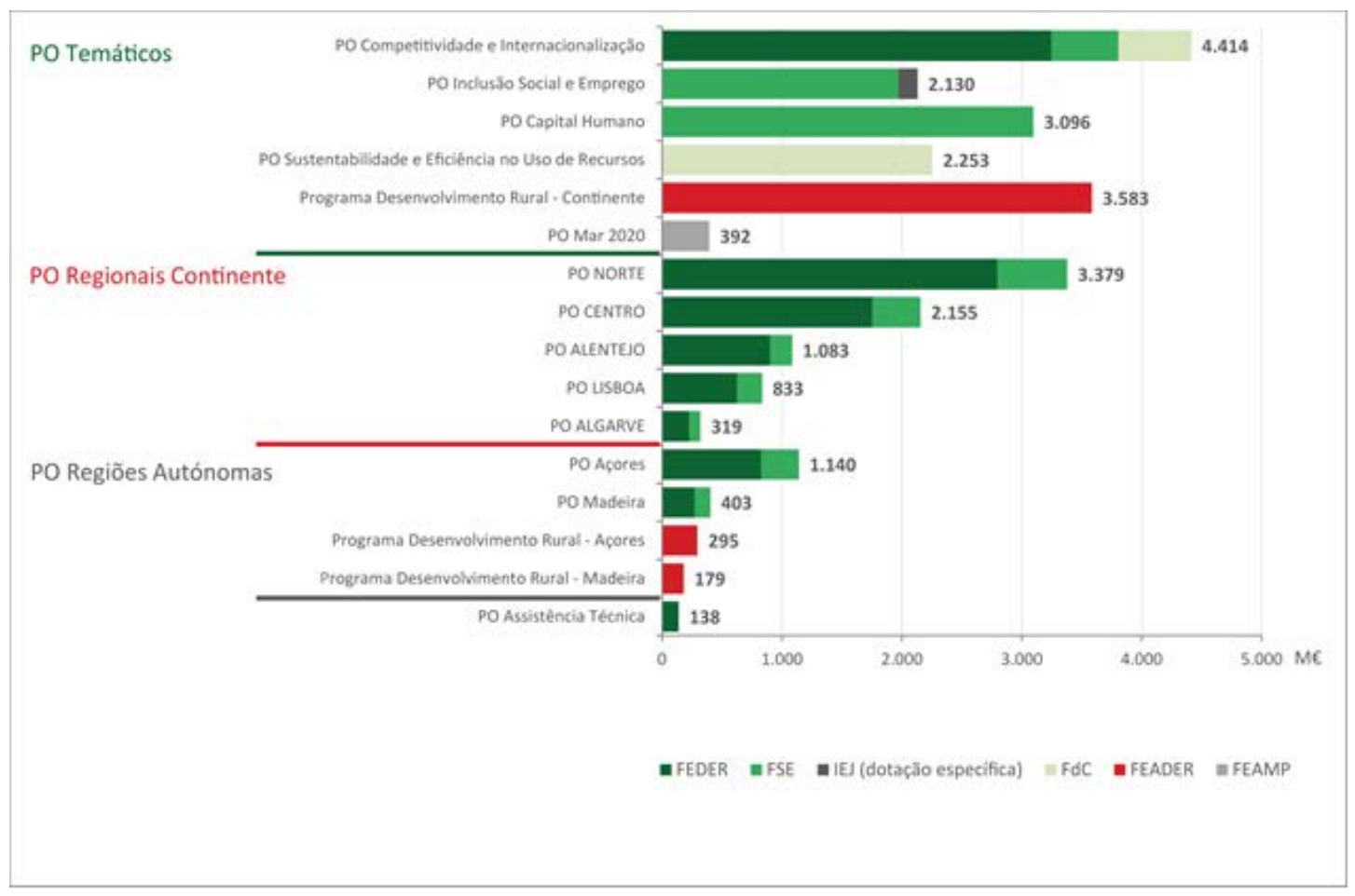

\section{METHODOLOGY}

After collecting the information available on the website of the $\mathrm{H} 2020$ managing body for North of Portugal - http://www.norte2020.pt (data until 9/30/2018), the analysis was structured in relation to the four large areas of intervention: 1) Municipal investment; 2) Business investment; 3) Science and technology; d) territorial approaches. 
In each area, the following information was collected: total support from the $\mathrm{H} 2020$ program, eligible investment, total investment and number of projects supported. After the data were collected, they were organized and processed, and results were obtained to answer the questions asked.

\section{RESULTS}

With regard to higher education, and despite the efforts made in the last decades, it is vital to continue efforts to meet the challenges associated with achieving the EU 2020 targets. The strategy of qualifying human capital at the higher education level will also seek to address the mismatch between qualifications produced and those demanded by the labor market, by bringing higher education offerings closer to the needs identified, together with the strengthening of the multidisciplinary qualifications of the graduates with a view to facilitating their mobility in the labor market. This strategy also aims to increase the attractiveness of higher education offerings in connection with the business environment. The National Reform Program 2014 of Portugal (PNR 2014) presents the "Program for Transfer of Knowledge and Technology for the Enterprise", in which a commitment is made to increase the involvement of companies in a consortium with R \& D Universities / Institutions, as well as the international partnerships between Portuguese higher education institutions and foreign institutions, with a focus on entrepreneurship and innovation.

In this context, the Structural Funds should continue to contribute to the support of higher education scholarships for underprivileged pupils, with a view to promoting equal opportunities in access to this level of education, as well as improving levels of school success. Public policy interventions co-financed by Community funds at the level of higher education should also pursue as objectives:

1 to increase the population with higher education by strengthening links between vocational training courses in secondary education and polytechnic education, while responding to the needs of regional economies;

2 to promote the mobility of recent graduates and teachers as a catalyst for the creation of European networks;

3 rationalize training provision in higher education by adapting it to the needs of the labor market, in particular through the creation of short-term higher education, ISCED level 5, developed by the Polytechnic Institutes in partnership with regional stakeholders;

4 supporting the development of high-quality innovative doctoral and post-doctoral programs; and

5 to build and strengthen specialist expertise in emerging fields in the field of the marine economy, ensuring excellence and incorporation into international networks.

With regard to investments in education infrastructures, the previous programming periods, in particular the NSRF (National Strategic Reference Framework), were marked by a number of investments, in particular at the level of basic and secondary education.

These investments can not be dissociated from the results achieved in several indicators in recent years, in particular in education indicators and those which specifically contribute to the achievement of the 2020 targets for reducing the early school leaving rate and population in the segment between 30 and 34 years with higher education. Despite the investments already made, the education landscape is still characterized by marked regional asymmetries demanding different responses to the constraints identified, based on a strategic action plan that guarantees territorial cohesion in the field of educational equipment, focused on the identification of very specific and high priority interventions.

At the level of higher education, the efforts to resize and adapt the public network and the training offer should be favored, especially through a more intense collaboration within each sub-sector (university and polytechnic) and between institutions of both subsectors. "

In order to follow up, Portugal has incorporated in its National Reform Program (NRP) a set of priorities and targets aligned with the Europe 2020 strategy, which include increased employment, people skills, environment and energy, investment in research and development (R \& D) and innovation and a clear focus on combating poverty and social exclusion.

The programming principles that confirm the policy of Research and Innovation for the period 20142020 are described in the Partnership Agreement (Portugal 2020) adopted between Portugal and the European Commission. 
The Partnership Agreement brings together investment under the European Structural and Investment Funds for the economic, social and territorial development of Portugal in 2014-2020. These programming principles are aligned with Intelligent, Sustainable and Inclusive Growth, pursuing the Europe 2020 Strategy.

The Partnership Agreement allocates $€ 25$ billion to Portugal by 2020, with more than $€ 1$ billion being reserved for Science.

The Research and Innovation Strategy for Intelligent Specialization is crucial for the public funding of research and innovation in Portugal as it constitutes ex ante conditionality of the Partnership Agreement for investment priorities in research and innovation. It identifies the major investments around which the investment should be directed in the period 2014-2020, maximizing the benefits of a coordinated intervention in the different spaces with which the National Research and Innovation System (SI \& I) interconnects.

It is a multi-level strategy where the National Research and Innovation Strategy (NRIS) comprises national challenges and their alignment with the seven regional strategies.

Alignment occurs at both thematic and policy-mix priorities and in the governance model, which includes cross-participation from the regional level to the national level and vice versa.

\section{CONCLUSIONS}

Overall, we can conclude that under Horizon 2020, each euro of European Union support to the Public and Private Institutions of the Northern Region of Portugal provides an investment in the regional economy of 1,71 euros. As shown, these investments vary according to the type of investments, namely public investments in which the impact is $135 \%$ on Community support, $136 \%$ on investment in science and higher education, $156 \%$ on territorial investments and finally doubles 205\%) in corporate investments. In this way, we can see the importance of the current $\mathrm{H} 2020$ community framework, regional development, national development and the European Union as a whole, in the logic of territorial cohesion. Emphasize the importance of investment in the business area, which represents more than $50 \%$ of the total investment made up to September 30, 2018.

When compared to the European Union's, data and objectives for the current financing framework (2014-2020), where the total grant endowment stands at 351,8 billion, for an expected overall investment of 450 billion (multiplier expected for the investment of 1,28), it can be seen that the NUT III - North of Portugal up to the date of the analysis can overcome this indicator presenting a global multiplier of 1,71 on the received support.

\section{REFERENCES}

[1] Admiraal, J.F., Musters, C.J.M., \& Snoo, G.R. (2015). The loss of biodiversity conservation in EU research programmes: Thematic shifts in biodiversity wording in the environment themes of EU research programmes FP7 and Horizon 2020. Journal for Nature Conservation, 30, 12-18. doi: https://doi.org/10.1016/j.jnc.2015.12.008

[2] Agência para o Desenvolvimento e Coesão, IP (setembro de 2016) "Boletim Informativo dos Fundos da União Europeia" http://www.qren.pt/np4/file/4954/bol_fundos_6.pdf

[3] BARCA, Fabrizio (2009), An Agenda for a Reformed Cohesion Policy: a Place-based Approach to Meeting European Union Challenges and Expectations, relatório independente preparado para a Comissária da Política Regional, Abril, s/ local; igualmente acessível em http://ec.europa.eu/regional_policy/policy/future/pdf/report_barca_v0306.pdf

[4] Brunner, C., Birbaumer, N., Blankertz, B., Guger, C., Kübler, A., Mattia, D., ... Müller-Putz, G. R. (2015). BNCl Horizon2020: Towards a roadmap for the BCl community. Brain-Computer Interfaces, 2(1), 1-10. doi: https://doi.org/10.1080/2326263X.2015.1008956

[5] Calzada, I. (2013). Critical social innovation in the smart city Era for a city-regional European Horizon 2020. P3T Journal of Public Policies \& Territories, Social Innovation and Territory, 6, 1-20. Retrieved from https://ssrn.com/abstract=2506952

[6] Charbit, C. (2011). Governance of Public Policies in Decentralised Contexts: The Multilevel Approach. OCDE Regional Development Working Papers, 2011/04. OCDE Publishing. 
[7] Comissão Europeia (2010). Investing in Europe's Future [Relatório], novembro 2010. $5^{\circ}$ Relatório sobre a coesão económica, social e territorial. Bruxelas. Disponível em: http://ec.europa.eu/ regional_policy/sources/docoffic/official/reports/cohesion5/pdf/5cr_part1_en.pdf

[8] COMPETE: Programa Operacional Fatores de Competitividade "Estrutura" http://www.pofc.qren.pt/ compete/estrutura [15-10-2016].

[9] COMPETE: Programa Operacional Fatores de Competitividade "Incentivos às Empresas" http://www.pofc.qren.pt/areas-do-compete/incentivos-as-empresas.

[10] Enger, S.G., \& Castellacci, F. (2016). Who gets Horizon 2020 research grants? Propensity to apply and probability to succeed in a two-step analysis. Scientometrics, 109, 1611-1638. doi: https://doi.org/10.1007/s11192-016-2145-5

[11] Filos E. (2013). Manufacturing innovation and Horizon 2020. In Kovács G. L., \& Kochan D. (eds.), Digital product and process development systems. NEW PROLAMAT 2013. IFIP Advances in Information and Communication Technology (vol. 411, pp. 1-10). Springer: Berlin, Heidelberg. doi: https://doi.org/10.1007/978-3-642-41329-2_1

[12] Galsworthy, M., \& McKee, M. (2013). Europe's 'Horizon 2020' science funding programme: how is it shaping up? Journal of Health Services Research \& Policy, 18(3), 182-185. doi: https://doi.org/10.1177/1355819613476017

[13] Granieri, M., \& Renda, A. (2012). Innovation law and policy in the European Union: Towards Horizon 2020. New York: Springer. ISBN 978-88-470-1917-1.

[14] Guedj, D., \& Ramjoué, C. (2015). European Commission Policy on Open-Access to scientific publications and research data in Horizon 2020. Biomed Data Journal, 1(1), 11-14. doi: http://dx.doi.org/10.11610/bmdj.0110

[15] Kalisz, D. E., \& Aluchna, M. (2012). Research and innovations redefined: Perspectives on European Union initiatives and strategic choices on horizon 2020. European Integration Studies, 6, 140-149. doi: http://dx.doi.org/10.5755/j01.eis.0.6.1426

[16] Katsanis, C. J., \& Davidson, C.H. (1995). Horizon 2020: How will North America Build? International Journal of Architectural Management Practice \& Research, 9, 146-162. Retrieved from https://www.researchgate.net/publication/288947381_Horizon_2020_how_will_North_America_bu ild

[17] McCarthy, S. (2014). How to write a competitive proposal for Horizon 2020: A handbook for research managers. Publication Watergrasshill: Hyperion. ISBN 978-0954625733.

[18] Observatório do QREN (2013). A contratualização como expressão da governação multinível: as lições do QREN e os desafios 2014-2020. Braga: 19 Congresso da APDR, 20 de junho 2013.

[19] Orientações para a contratualização com subvenção global entre as autoridades de gestão dos POR e as associações de municípios baseadas em NUTS III (2008). Deliberação aprovada em 19 de Março de 2008.2 Disponível em: http://maiscentro.qren.pt/private/admin/ficheiros/uploads/ocontratualizacao.pdf

[20] Rollat, A., Guyonnet, D., Planchon, M., \& Tuduri, J. (2016). Prospective analysis of the flows of certain rare earths in Europe at the 2020 horizon. Waste Management, 49, 427-436. doi: https://doi.org/10.1016/j.wasman.2016.01.011

[21] Tulla, A. F., Vera, A., Badia, A., Guirado, C., \& Valldeperas, N. (2014). Rural and regional development policies in europe: Social farming in the common strategic framework (horizon 2020). Journal of Urban and Regional Analysis, 6(1), 35-51. Retrieved from https://www.ceeol.com/search/article-detail?id=727026

[22] Veugelers, R., Cincera, M., Frietsch, R., Rammer, C., Schubert, T., Pelle, A., ... Leijten, J. (2015). The impact of Horizon 2020 on innovation in Europe. Intereconomics, 50(1), 4-30. https://doi.org/10.1007/s10272-015-0521-7

[23] Vilela, Gomes \& Morais (2017) Government Transparency: Reality or Mirage?, Lex Localis - Journal Of Local Self-Government, DOI: https://doi.org/10.4335/15.3.725-736(2017)

[24] Walshe, K., McKee, M., McCarthy, M., Groenewegen, P., Hansen, J., \& Figueras, J. (2013). Health systems and policy research in Europe: Horizon 2020. The Lancet, 382(9893), 668-669. doi: https://doi.org/10.1016/S0140-6736(12)62195-3 
[25] Young, M. (2015). Shifting Policy Narratives in Horizon 2020. Journal of Contemporary European Research, 11 (1), 16-30. Retrieved from http://jcer.net/index.php/jcer/article/view/634 